\title{
An Examination of Tax E-Filing Acceptance in Sarawak Applying UTAUT
}

\author{
Masriah Alias, Idawati Ibrahim* \\ Tunku Puteri Intan Safinaz Scool of Accountancy, Universiti Utara Malaysia, Malaysia
}

\begin{abstract}
The usage of tax e-filing in Malaysia has continuously shown a positive and increasing trend from year to year after a decade of its introduction. However, the acceptance rate for salaried taxpayers in Sarawak is only about $50 \%$, making the study of this situation necessary. The aims of this study are twofold: (1) to examine the level of tax e-filing acceptance in Sarawak, and (2) to investigate the relationships between performance expectancy, effort expectancy, social influence, facilitating condition, and the intention to accept tax e-filing system in Sarawak, Malaysia. This study uses the Unified Theory of Acceptance and Use of Technology (UTAUT) as the underpinning theory. A total of 630 questionnaires was distributed to salaried taxpayers in Sarawak. The descriptive analysis and multiple regression analysis using IBM SPSS version 26 were utilised to achieve the objectives. It was found that taxpayers in Sarawak have a high level of intention to use tax e-filing. The findings also show that performance expectancy and facilitating conditions have a significant positive relationship, social influence has a significant negative relationship. In contrast, effort expectancy was found to be insignificant. Since the IRBM is currently taking steps to enhance services delivery using the e-filing system, the results may assist them to plan a more effective strategy to provide a better tax e-filing system to Sarawak salaried taxpayers, specifically other states that have a similar background to Sarawak.
\end{abstract}

Keywords: Unified Theory of Acceptance and Use of Technology (UTAUT), tax e-filing system, performance expectancy, facilitating conditions, social influence.

JEL Classification: H24, D83, E61

Paper Type: Research

*Corresponding author: E-mail: idawati@uum.edu.my 


\section{INTRODUCTION}

The technology has rapidly changed over time and is becoming increasingly sophisticated, which could be more challenging to both the tax administrator and taxpayers (Ibrahim, 2013). Nevertheless, technological advancement has become crucial, especially with the Fourth Industrial Revolution (IR 4,0), where technology affects our lives, including economic, social, cultural, and human environments. Those who are not technologically savvy may find themselves left behind in society. As a result, taxpayers need to adapt and deal with tax services using a technology-based system.

The Inland Revenue Board of Malaysia (IRBM) is a tax authority responsible for collecting and administering income taxes in Malaysia. In line with the Malaysian government's initiative in embarking on the e-Government, the IRBM introduced an electronic tax filing (e-filing) application to modernise tax filing for taxpayers. Besides improving the efficiency in processing or dealing with the filing submission in the IRBM (Inland Revenue Board of Malaysia, 2009), it also increases the public services quality to their clients. The system is also a popular choice among most individual taxpayers. It is convenient compared to paper filling and manual submission.

However, in Sarawak, a Malaysian state located in Borneo Island, internet penetration has been considered lacking compared to most other states in peninsular Malaysia, especially during the previous years (Department of Statistics Malaysia, 2020). This may be due to the size of Sarawak, which is the largest state in Malaysia, as technology penetration may be difficult for rural or remote areas. Only recently, the Sarawak Chief Minister, Datuk Patinggi Abang Johari Tun Openg, recognised the importance of internet connection in Sarawak and said, "Because if you do not have internet, you cannot work these days" (Aubrey, 2020).

Moreover, statistical evidence shows an unsatisfactory achievement of using the tax efiling system in Sarawak even though the system has existed for more than ten years. Statistical information from the IRBM indicates that the tax returns submission rate through e-filing among salaried taxpayers in Sarawak from 2013 to 2015 was only between $41 \%$ and $50 \%$ (Information received from personal communication through email from the Unit of Statistics, Tax Operation Department, IRBM). In addition, from one of the authors personal observations as a tax official in Sarawak with more than five years of experience, some salaried taxpayers seemed not confident to perform e-filing and still needed assistance from IRBM to electronically file their tax returns. The IRBM needs to provide service counters with computer and internet facilities to help individual taxpayers file their tax return forms via the e-filing system every year. This situation motivated the authors to understand the tax e-filing situation in Sarawak and explore ways to increase the adoption of the e-filing system among salaried taxpayers.

This study's objectives are twofold. First, it aims to identify the level of acceptance on tax e-filing among Sarawak taxpayers by examining the taxpayers' level of intention to use tax e-filing and perception towards the system in terms of its usability (performance expectancy), easiness to use the system (effort expectancy), how essential persons in taxpayers live to influence their decision (social influence), and how infrastructure (facilitating conditions) surrounding the system in Sarawak. Second, the study is aimed to investigate the relationships between the factors mentioned above (i.e., performance expectancy, effort expectancy, social influence, facilitating conditions, and behavioural intention). This study is significant to IRBM specifically to comprehend the condition of tax 
e-filing in Sarawak. The findings on factors that are found statistically significant can be suggested to the tax authority to be utilised in making the strategy to improve the tax efiling system and its usage among taxpayers in Sarawak.

For the arrangement of this paper, the literature review follows the introduction. It discusses the underpinning theory, the Unified Theory of Acceptance and Use of Technology (UTAUT) and previous studies related to the variables tested in this study to develop relevant hypotheses. The methodology adopted for this study is discussed, with a conclusion.

\section{LITERATURE REVIEW AND HYPOTHESES DEVELOPMENT}

\subsection{The Unified Theory of Acceptance and Use of Technology (UTAUT)}

The UTAUT was developed by (Venkatesh et al., 2003) by combining a few previous technology acceptance related models such as the Technology Acceptance Model (TAM), Motivational Theory, Model of PC Utilisation, Theory of Reasoned Action (TRA), and Theory of Planned Behaviour (TPB). There are four independent variables available in this model that predict behavioural intention and actual behaviour. The three determinants, performance expectancy, effort expectancy, and social influence, directly relate to behavioural intention. In contrast, one variable, facilitating conditions, directly relates to users' actual behaviour. The relationships are moderated by either age, gender, experience, and/or voluntariness of use.

Two of the UTAUT variables were adapted from the original TAM. The variables are performance expectancy (PE) which is similar to perceived usefulness (PU), and effort expectancy (EE), which was modified from perceived ease of use (PEOU). In a recent study that utilised UTAUT, the names were sometimes used interchangeably between PU and PE and PEOU and EE as they carry the same meaning (Rakhmawati et al., 2020). The original UTAUT attempted to explain how individual differences influence technology use by including demographic items as moderators. However, most technology acceptance studies (Ambali, 2009; Carter \& Schaupp, 2009; Ilias et al., 2008; Lu et al., 2010; Mamta, 2012; Ojha et al., 2009; Ozgen \& Turan, 2007; Sharma et al., 2011) only tested the four original UTAUT independent variables towards behavioural intention, not the actual behaviour. This may be due to the strength of the variables themselves, which can predict behavioural intention.

Some studies also extend the UTAUT model to include other factors in the model. Examples of the factors are perceived risk, optimism bias (Abdul-Manaf et al., 2010; Ambali, 2009; Hussein et al., 2011; Lai et al., 2004; Mamta, 2012; Schaupp \& Carter, 2009; Schaupp et al., 2010; Sharma et al., 2011) and perceived credibility (Anuar \& Othman, 2010). As a preliminary study in Sarawak, the researchers retained the original four independent variables to achieve the intended objectives of this study.

\subsection{Performance Expectancy}

Performance expectancy (PE) was defined by Venkatesh et al. (2003, p. 447) as "the degree to which an individual believes that using the system will help him or her to attain gains in job performance". PE is a dominant predictor of technology acceptance in many studies (Carter \& Schaupp, 2009; Davis, 1989; Fu et al., 2006; Schaupp et al., 2010; 
Venkatesh et al., 2003). Findings from the studies show that PE has a significant positive relationship with intention towards technology acceptance.

However, some studies have found an insignificant relationship between PE and behavioural intention, especially in tax e-filing studies. For example, a study by Wu and Chen (2005) found an insignificant relationship between PE and intention towards technology. The study on tax e-filing acceptance in Taiwan revealed that PE is insignificant to influence the behavioural intention to use tax e-filing in Taiwan during that time. This was probably because the system was still new at the time. Most people may be sceptical about using a technological device or system because they have no experience with the usefulness of the system. A recent study by Tahar et al. (2020) also found an insignificant result for the direct relationship between PE (perceived usefulness in the study) and intention to use e-filing in Indonesia.

Since many studies have found PE to have a positive effect on the intention to accept efiling as discussed above, the same pattern of prediction would be applied in this study and the following hypothesis was developed:

H1: "There is a significant positive relationship between performance expectancy and intention to use tax e-filing system in Sarawak".

\subsection{Effort Expectancy}

Effort expectancy (EE) is the level of effort that needs to be used or familiar with a system (Venkatesh et al., 2003). It depends on whether the system is perceived as accessible or challenging to be used by the user. Suppose a potential user perceives the system as difficult to use. In that case, it may hinder the intention to adopt the system or technology. Therefore, EE was also a strong determinant of behavioural intention, as found in previous studies such as Carter et al. (2011) and Lu and Nguyen (2016). Evidence from prior studies has shown that the results of EE on intention are mixed. Studies that found EE as a significant positive predictor of technology acceptance include Lu (2016), Mamta (2012), Carter et al. (2011), Sharma et al. (2011), Ojha et al. (2009) and Wang (2002). More recent studies that found a significant and positive direct relationship between EE and intention to use tax e-filing are Tahar et al. (2020) in Indonesia and Ismail et al. (2021) in Malaysia. Razak et al. (2020) indicate in their study that salaried taxpayers from government servants should have no problem using tax e-filing systems as they have high technological proficiency.

However, in a study that utilised TAM, PEOU, which has a similar meaning with PE, was the second important determinant after perceived usefulness that motivated the behavioural intention towards technology/system usage (Davis, 1989). In a study by Moore and Benbasat (1991), it was found that people tend to reject a system if it requires advanced skills and challenging learning levels. In other words, the complexity of a system or technology may decrease the effect of EE on the intention to adopt a technology. A study by Schaupp and Carter (2009) indicated that EE was not shown to be a significant predictor of behavioural intention. However, the study highlights the necessity for an efiling system to be easy to use to accommodate not technologically savvy individuals. Other studies that found insignificant results of EE were Schaupp et al. (2010) and Chang et al. (2005). 
Based on the observation of taxpayers in Sarawak, this present study found EE as relevant and essential to be included as an independent variable in predicting the behavioural intention towards the tax e-filing system. As a result of the discussion presented earlier, it is hypothesised that:

H2: "There is a significant positive relationship between effort expectancy and intention to use tax e-filing system in Sarawak".

\subsection{Social Influence}

Social influence (SI) is "the degree to which an individual perceives that important others believe he or she should use the new system" Venkatesh et al. (2003, p. 451). SI also indicates an enhanced status in a social system when an innovation or technological system is used by a person (Moore \& Benbasat, 1991). This factor influences behavioural intention as individuals believes others' opinion could result in the individual's acceptance of the technology (Lee et al., 2010). The SI as a determinant of technology acceptance was developed from several constructs in other theories.

As indicated in Venkatesh et al. (2003) and Schaupp and Carter (2009), most prior research used SI to predict behavioural intention directly. The exact scope has been internationally tested on e-filing intention and acceptance, for instance, Carter and Schaupp (2009) in the USA; and Mamta (2012) to predict SI on the e-filing behavioural intention in India. Al-Okaily et al. (2020), who utilised the UTAUT model as the underpinning theory in the Jordan set, found that SI positively influenced Jordan's acceptance of digital payment.

In Malaysia, several studies on technology acceptance have used SI as a determinant of behavioural intention. For example, Hussein et al. (2011) applied SI as a direct determinant of e-filing intention. Meanwhile, Ramayah et al. (2009) and Anuar and Othman (2010) used subjective norms in their studies to directly determine intention. In conclusion, as SI was found to have a significant and positive effect in many previous studies as discussed above, this study posits that:

H3: "There is a significant positive relationship between social influence and intention to use tax e-filing system in Sarawak".

\subsection{Facilitating Conditions}

Facilitating conditions (FC) refer to the degree to which a person believes that the organisational and technical infrastructures are in place to support technology usage (Venkatesh et al., 2003). Organisational and technical infrastructures are the resources and support available to perform a behaviour. This factor is considered similar to perceived behavioural control in TPB (Ajzen, 1991; Taylor \& Todd, 1995).

In the original UTAUT model, FC is tested directly on user behaviour. However, several studies have directly tested the FC towards behavioural intention instead of usage behaviour (Abdul Aziz, 2012; Ambali, 2009; Lu, 2016; Sharma et al., 2011; Suki \& Ramayah, 2010). It was suggested by Brown et al. (2010) that the effect of FC directly influences the intention to use the technology introduced. The study by Schaupp and Carter (2009) found that FC had a positive and significant impact on behavioural intention. Ambali (2009) also obtained the same results, which showed that FC directly impacts 
behavioural intention. Suki and Ramayah (2010) also found that FC is significant in determining user acceptance of e-government services.

Based on the analysis from the literature, $\mathrm{FC}$ has a positive effect on behavioural intention. Hence, this present study considered FC as part of the independent variable in predicting the behavioural intention of Sarawakian in using the e-filing system. The following hypothesis was developed:

H4: "There is a significant positive relationship between facilitating conditions and intention to use tax e-filing system in Sarawak".

\subsection{Behavioural Intention}

Fishbein and Ajzen (1975) described intention as the motivational element that initiates someone's behaviour. It is also described as how much energy someone is ready to engage when executing a behaviour. Ajzen (2002) defined behavioural intention as a signal of an individual's inclination to execute an action. It is assumed to be a representation or proxy of behaviour. Behavioural intention formation constitutes the attitude towards the behaviour in terms of normative belief and subjective norms. Using behavioural intention to represent actual behaviour has been utilised in many studies (Ajzen, 1991; Taylor \& Todd, 1995; Venkatesh et al., 2003). Thus, this study also utilised behavioural intention as the proxy of actual behaviour.

To conclude the literature review, this study examines the level of e-filing acceptance among Sarawak taxpayers. Using UTAUT as underpinning theory, the current model dropped the moderating variables of "age", "gender", "experience", and "voluntariness of use" because this is a preliminary study for Sarawak's tax e-filing acceptance, whereby the aim is to identify the direct relationships. The four original determinants from Venkatesh et al. (2003) (i.e., performance expectancy, effort expectancy, social influence, and facilitating conditions) were tested as direct relationships toward the behavioural intention. As Venkatesh et al. (2003) proposed, Usage behaviour was also excluded in this study as the intention is used as the proxy for actual behaviour. The framework for this study is illustrated in Figure 1. 


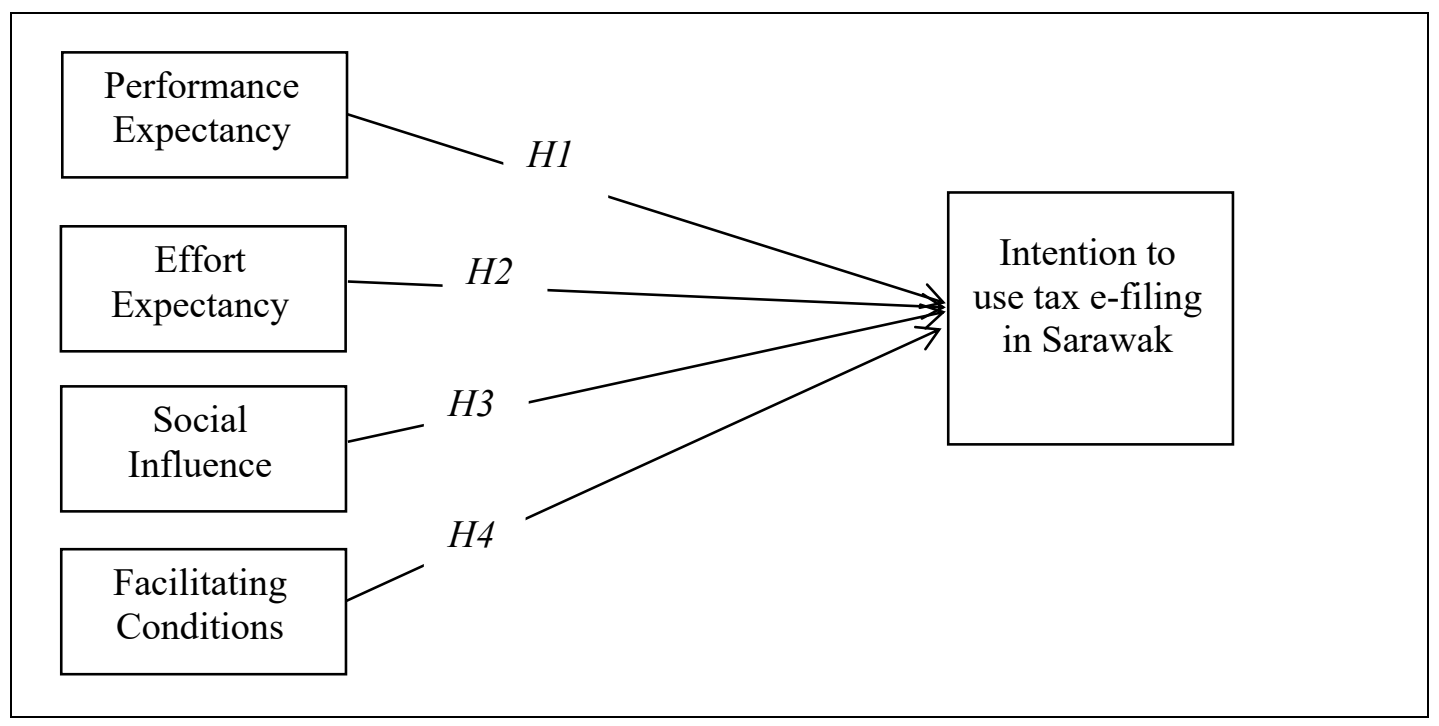

Figure 1. A study research framework for intention to use tax e-filing in Sarawak, Malaysia

\subsection{METHODOLOGY}

This study utilised the quantitative research method by employing a questionnaire survey. Granting the population of individual registered taxpayers with salaried income in Sarawak was about 337,744 in 2015 (Unpublished data from communication through email with the Profiling Unit, IRBM Sibu Branch, 29 June 2016), a survey questionnaire was distributed randomly to 630 respondents. The number of samples was more than the suggestion by Krejcie and Morgan (1970) and (Sekaran \& Bougie, 2016) to tackle the non-response rate. It was considered adequate for statistical analysis with five variables in the model, as suggested by Hair et al. (2010). Data collection was performed in October 2016.

The questionnaire consists of 38 structured questions which asked the respondents to provide their opinion based on a 5-point Likert scale, ranging from "1 = strongly disagree" to "5 = strongly agree" on all statements related to the dependent variable and four independent variables. Six items in the questionnaire measured PE, while seven items measured EE and FC. SI and intention to use tax e-filing were measured through three items for each. All measurement items were adapted from Venkatesh et al. (2003). Although all items were adapted from a reliable source, a pilot study and tests to determine the reliability and validity through Cronbach's alpha and factor analysis were also conducted. Results from both analyses indicated that the data were reliable and valid for further data analysis.

Data analysis was conducted using the Statistical Package for Social Science Software (SPSS). This study employed the quantitative research method and statistical analysis, parametric assumptions such as the normality and multicollinearity tests were conducted. The results from SPSS analysis for normality curve, kurtosis and skewness of the data distribution indicated that the data were normally distributed. For the reliability analysis, Cronbach's alpha values were used, and the result showed that the values were between 0.846 and 0.970 . Meanwhile, for construct validity, factor analysis was performed using PCA with varimax rotation. The results indicated that the KMO values were above the 
threshold of 0.50 for all the variables. The multicollinearity issue was examined using the Pearson correlation coefficient. The results also indicated that the data had no multicollinearity issue. Therefore, the primary data analysis was conducted to achieve the study objectives.

Descriptive analysis was conducted to determine the acceptance level of tax e-filing among Sarawak taxpayers by investigating their intention and perceptions towards PE, $\mathrm{EE}, \mathrm{SI}$ and FC. Multiple regression analysis was performed to test all the hypotheses developed in this study to achieve the second objective: to investigate the relationships between PE, EE, SI, FC and the intention to accept the e-filing system in Sarawak, Malaysia. Multiple regression is a well-known statistical test to investigate the relationships between predictors and dependent variables. It is also a realistic, practical, and robust method for research on the science of behaviours (Kerlinger et al., 2000). Moreover, as the framework of this study is considered simple, multiple regression is considered most appropriate as the parametric assumption tests have been fulfilled by the data collected.

\subsection{RESULTS AND DISCUSSION}

Using the self-administered data collection procedure, a total of 397 usable questionnaires were received, giving a response rate of $63 \%$. The information regarding the respondents' background is presented in Table 1.

Table 1. Respondents' Background ( $n=397)$

\begin{tabular}{lll}
\hline Item & Frequency & Percent (\%) \\
\hline Gender: & 187 & 47.10 \\
Male & 210 & 52.90 \\
Female & 26 & \\
\hline Age: & 178 & 6.5 \\
24 and under & 82 & 44.8 \\
$25-34$ & 85 & 20.7 \\
$35-44$ & 26 & 21.4 \\
$45-54$ & & 6.5 \\
$55-64$ & 131 & \\
Marital Status: & 264 & 33.0 \\
Single & 2 & 66.5 \\
Married & & 00.5 \\
Others & 135 & \\
Ethnicity: & 95 & 34.0 \\
Malay & 160 & 23.9 \\
Chinese & 5 & 40.3 \\
Aboriginal Sarawak & & 01.3 \\
Others & 14 & \\
\hline Location: & 2 & 3.5 \\
Kuching & 6 & 0.5 \\
Sarikei & 375 & 1.5 \\
Miri & & 94.5 \\
Sibu & &
\end{tabular}




\subsection{Tax E-Filing Acceptance's Level among Sarawak Taxpayers}

Mean and standard deviation was used to measure the level of tax e-filing acceptance for all the variables tested in this study. In interpreting the mean score, Nik Muhammad et al. (2010) suggest that scores of less than 2.33 are low level, 2.33 to 3.67 are moderate level, while 3.67 and above are considered as high level. Generally, using the 5-point Likert scale, the mean for all variables in this study was between 3.64 and 4.22 . Specifically, the highest score is shown by intention to use tax e-filing with a mean score of 4.22. This is followed by PE (mean = 4.14), FC (mean = 3.79) and EE (mean = 3.73). Finally, SI showed a lower mean score at 3.64. Table 2 shows the details of the descriptive results.

Table 2. Descriptive Results $(n=397)$

\begin{tabular}{lllll}
\hline & Minimum & Maximum & Mean & $\begin{array}{l}\text { Standard } \\
\text { Deviation }\end{array}$ \\
\hline Performance Expectancy (PE) & 1 & 5 & 4.14 & 0.720 \\
Effort Expectancy (EE) & 1 & 5 & 3.73 & 0.579 \\
Social Influence (SI) & 1 & 5 & 3.64 & 0.989 \\
Facilitating Conditions (FC) & 1 & 5 & 3.79 & 0.607 \\
Behavioral Intention & 1 & 5 & 4.22 & 0.847 \\
\hline
\end{tabular}

The results indicate that the salaried taxpayers in Sarawak have a high level of intention to use tax e-filing (mean score for behavioural intention $=4.22$. They also have a high level of belief that e-filing is useful to help them file tax returns (mean score for PE $=4.14$ ) and does not require high effort in using it (mean score for $E E=3.73$ ). Moreover, they showed a high level of perception towards facilitating conditions available for them to e-file (mean score for $F C=3.79$ ). This may be due to the programme provided by the IRBM every year, which facilitated the taxpayers with computers, the internet, and officers to help them use the system. However, the level of social influence in influencing the adoption of e-filing is at the moderate level (mean score for $\mathrm{SI}<3.67$ ). Overall, it can be concluded that Sarawakian salaried taxpayers have a high use of e-filing to complete their income tax returns annually. This indicates a welcoming signal from the taxpayers.

\subsection{The Relationships between Independent Variables and Intention to Use Tax E- Filing System in Sarawak}

Multiple analysis was utilised to test all the hypotheses in this study. The model tested for this study comprised four direct independent variables and one dependent variable. The adjusted $R^{2}$ was used to evaluate the model tested for the relationships. The adjusted $R^{2}$ for the current model was $67.7 \%$, which indicated that the model explains $67.7 \%$ of the variance in the intention to use tax e-filing in Sarawak. The results of the relationships tested for this study using multiple regression analysis are presented in Table 3. 
Table 3. Multiple Regression Analysis: Result of Relationships

\begin{tabular}{|c|c|c|c|c|c|}
\hline \multirow[t]{2}{*}{ Model } & \multicolumn{2}{|c|}{$\begin{array}{l}\text { Unstandardised } \\
\text { Coefficients }\end{array}$} & \multicolumn{2}{|l|}{$\begin{array}{l}\text { Standardised } \mathrm{t} \\
\text { Coefficients }\end{array}$} & \multirow[t]{2}{*}{ Sig. } \\
\hline & B & Std. Erro & r Beta & & \\
\hline (Constant) & -.192 & .165 & & -1.166 & .244 \\
\hline $\begin{array}{l}\text { Performance } \\
\text { (PE) }\end{array}$ & .559 & .067 & .475 & 8.400 & $.000^{* *}$ \\
\hline Effort Expectancy (EE) & .046 & .090 & .032 & .512 & .609 \\
\hline Social Influence (SI) & -.052 & .031 & -.061 & -1.684 & $.093^{*}$ \\
\hline Facilitating Conditions (FC) & .559 & .071 & .400 & 7.834 & $.000^{* *}$ \\
\hline
\end{tabular}

Dependent Variable: Intention to Use Tax E-Filing

**Significant at $p<0.05$ level; * Significant at $p<0.1$ level, Adjusted $R^{2}=0.677$

As indicated in Table 3, the relationship between PE and intention to use tax e-filing was significant and positive at $\mathrm{p}=0.000$. Therefore, $\mathrm{H} 1$ is supported. This means the higher the taxpayers' performance expectancy or perceived usefulness, the higher the intention to use the system or vice versa. Moreover, the Beta value of 0.475 indicated that the variable made the most substantial unique contribution in explaining the intention to use or accept tax e-filing in Sarawak. The finding supported previous studies which found a positive relationship between PE and behavioural intention, such as by Lu (2016) and Mamta (2012), and several Malaysian studies (Ambali, 2009; Anuar \& Othman, 2010; Lean et al., 2009).

However, the multiple regression result for the relationship between EE and the dependant variable was found to be insignificant with $p=0.609$. This means that $\mathrm{H} 2$ was not supported. The result indicated that taxpayers in Sarawak do not bother about how much effort is required to operate the electronic system as long as the system is more valuable than traditional paper filing. The finding is similar to previous studies such as Chang et al. (2005), Carter et al. (2008) and Schaupp et al. (2010).

In testing the third hypothesis, the multiple regression results indicated a significant relationship between SI and the dependant variable. However, the direction of the relationship found in this study is negatively related (Beta $=-0.052)$. Therefore, the result does not support the hypothesis $(\mathrm{H} 3)$, which states that the relationship's direction is a significant positive relationship between SI and intention. In other words, the result means that SI is a significant factor to affect the e-filing usage, but negatively (i.e. higher SI would make lower e-filing usage intention or vice versa) the results indicate that it needs to be modified so that a positive social influence can be created among the taxpayers.

Finally, the fourth hypothesis on the relationship between FC and intention indicated a significant positive relationship at $p=0.000$. This means $\mathrm{H} 4$ is supported. The result indicated that more improved facilitating conditions provided by the IRBM would improve the intention to adopt the system or vice versa. This result is also in line with previous studies in Malaysia, such as Suki and Ramayah (2010) and Ambali (2009). The Beta coefficient of 0.400 for $\mathrm{FC}$, as shown in Table 3 , showed that the variable made a significant unique contribution towards the intention to use tax e-filing after PE. The result implies that in the current situation, the salaried taxpayers in Sarawak perceived that facilitation conditions provided by IRBM are important to make them use the system. 
Otherwise, poor facilitating conditions may reduce their likelihood to use the system. The finding suggests that future research can look further in this area because IRBM may not provide the facilitating conditions as previously, especially during a pandemic as what is currently happening with COVID-19. Taxpayers need to be educated and provided with good infrastructure to be independent in the future. Summary of hypotheses tested in this study and their results are presented in Table 4.

Table 4. Summary of Hypotheses and Results

\begin{tabular}{|c|c|c|}
\hline & Hypothesis & Result \\
\hline H1 & $\begin{array}{l}\text { "There is a significant positive relationship } \\
\text { between performance expectancy and } \\
\text { intention to use tax e-filing system in } \\
\text { Sarawak". }\end{array}$ & $\begin{array}{l}\text { Supported - } \\
\text { Significant positive }\end{array}$ \\
\hline H2 & $\begin{array}{l}\text { "There is a significant positive relationship } \\
\text { between effort expectancy and intention to } \\
\text { use tax e-filing system in Sarawak". }\end{array}$ & $\begin{array}{l}\text { Rejected - } \\
\text { Insignificant }\end{array}$ \\
\hline H3 & $\begin{array}{l}\text { "There is a significant positive relationship } \\
\text { between social influence and intention to } \\
\text { use tax e-filing system in Sarawak." }\end{array}$ & $\begin{array}{l}\text { Rejected - } \\
\text { Significant negative }\end{array}$ \\
\hline $\mathrm{H} 4$ & $\begin{array}{l}\text { "There is a significant positive relationship } \\
\text { between facilitating conditions and intention } \\
\text { to use tax e-filing system in Sarawak". }\end{array}$ & $\begin{array}{l}\text { Supported - } \\
\text { Significant positive }\end{array}$ \\
\hline
\end{tabular}

\subsection{CONCLUSION}

This study examined how Sarawak salaried taxpayers' intention towards the tax e-filing system. Two objectives were achieved: investigating the level of acceptance for electronic tax filing (e-filing) among Sarawak taxpayers and examining the relationships between the four independent variables (i.e. PE, EE, SI and FC) and intention to use the tax e-filing system. Generally, the findings show that Sarawak individual taxpayers highly accepted tax e-filing in Sarawak, given that most of the variables had high mean scores (more than 3.67) on 5-point Likert scale statements. $\mathrm{H} 1$ and $\mathrm{H} 4$ were supported for the four hypotheses tested, which indicated that PE and FC had significant and positive relationships towards intention to use tax e-filing. In contrast, $\mathrm{H} 2$ and $\mathrm{H} 3$, which are related to EE and SI, were not supported.

Practically, the results of this study can be used by the IRBM to strategise new methods to intensify the adoption of e-filing in Sarawak. The IRBM may emphasise how to increase taxpayers' awareness of the usefulness of the system by conducting a massive awareness programme to inform taxpayers about the advantages of the system compared to the manual paper filing. This includes an education programme for taxpayers on how to use the e-filing system. The IRBM may also provide better-facilitating conditions to improve the system's adoption by upgrading its capacity to avoid congestion during peak periods of submission to accommodate last-minute taxpayers to file their income tax returns when close to the filing due date. The IRBM may also provide better training to their staff to facilitate the taxpayers in using the system. In addition, the IRBM may collaborate with other governmental agencies to provide better internet and technological infrastructures like the Malaysian Communications and Multimedia Commission (MCMC) and Sarawak State Chief Minister. This study also contributes theoretically to the current literature on tax e-filing behavioural intention. Although a few studies have been conducted on the tax 
e-filing system, none were conducted in Sarawak's setting, where technology is considered lower than other places in Malaysia as when the study was conducted.

There are two limitations associated with this study. The first is that this study only utilised a sample from the population. Therefore, the results might not be generalised to the whole population as data on the actual population distribution was not compared. To overcome this limitation, it is suggested for future research to be conducted via mixed methods by including interviews with the respondents. The second limitation is associated with the independent variables tested in this study, which is limited to four variables (performance expectancy, effort expectancy, social influence and facilitating conditions). Future studies may incorporate more variables to explain better the acceptance of tax e-filing in a jurisdiction like Sarawak. Including a moderator or mediator is also recommended. Many previous studies have demonstrated that including them in a relationship may boost the significance level.

\section{REFERENCES}

Abdul-Manaf, N. A., Ishak, Z., \& Abdul-Warif, S. (2010). The acceptance of e-filing among individual taxpayers. 9th International Tax Administrative Conference, Sydney.

Abdul Aziz, S. (2012). The determinants of tax e-filing among tax preparers in Malaysia. World Journal of Social Sciences, 2(3), 182-188.

Ajzen, I. (1991). The theory of planned behaviour. Organisational behaviour and human decision processes, 50(2), 179-211. http://www.sciencedirect.com/science/article/pii/074959789190020T

Ajzen, I. (2002). Perceived behavioural control, self-efficacy, locus of control, and the theory of planned behaviour 1. Journal of applied social psychology, 32(4), 665-683.

Al-Okaily, M., Lutfi, A., Alsaad, A., Taamneh, A., \& Alsyouf, A. (2020). The determinants of digital payment systems' acceptance under cultural orientation differences: The case of uncertainty avoidance. Technology in Society, 63, 101367.

Ambali, A. R. (2009). E-government policy: Ground issues in e-filing system. European Journal of Social Sciences, 11(2), 249-266.

Anuar, S., \& Othman, R. (2010). Determinants of online tax payment system in Malaysia. International Journal of Public Information Systems, 6(1), 1.

Aubrey, S. (2020). Internet penetration in Sarawak must be improved to lure foreign investors, says Riot. The Borneo Post Online. https://www.theborneopost.com/

Brown, S. A., Dennis, A. R., \& Venkatesh, V. (2010). Predicting collaboration technology use: Integrating technology adoption and collaboration research. Journal of management information systems, 27(2), 954.

Carter, L., \& Schaupp, L. C. (2009). Relating Acceptance and optimism to e-file adoption. International journal of electronic government research, 5(3), 62-74.

Carter, L., Schaupp, L. C., \& Evans, A. (2008). Antecedents to e-file adoption: The US perspective. 41st Hawaii International Conference on System Sciences - 2008,

Carter, L., Schaupp, L. C., Hobbs, J., \& Campbell, R. (2011). The role of security and trust in the adoption of online tax filing. Transforming Government: People, Process and Policy, 5(4), 303-318.

Chang, I. C., Li, Y. C., Hung, W. F., \& Hwang, H. G. (2005). An empirical study on the impact of quality antecedents on taxpayers' acceptance of internet tax-filing systems. Government Information Quarterly, 22(3), 389 - 410. https://doi.org/10.1016/j.giq.2005.05.002

Davis, F. D. (1989). Perceived usefulness, perceived ease of use, and user acceptance of information technology. MIS Quarterly, 13(3), 319-340. http://www.jstor.org/stable/249008

Department of Statistics Malaysia. (2020). Usage of ICT and e-Commerce by Establishment. Retrieved August 8 from https://newss.statistics.gov.my/newss-portalx/ep/epProductFreeDownloadSearch.seam

Fishbein, M., \& Ajzen, I. (1975). Belief, attitude, intention and behaviour: An introduction to theory and research reading. Addison-Wesley. http://people.umass.edu/aizen/f\&a1975.html

Fu, J. R., Farn, C.-K., \& Chao, W. P. (2006). Acceptance of electronic tax filing: A study of taxpayer intentions Information \& Management, 43(1), 109 - 126. https://doi.org/10.1016/j.im.2005.04.001

Hair, J., Black, W., Babin, B., \& Anderson, R. (2010). Multivariate data analysis Upper Saddle River: Pearson Prentice Hall.[Links]. 
Hussein, R., Mohamed, N., Ahlan, A. R., \& Mahmud, M. (2011). E-government application: an integrated model on G2C adoption of online tax. Transforming Government: People, Process and Policy, 5(3), 225248.

Ibrahim, I. (2013). Electronic filing of personal income tax return in Malaysia: Determinants and compliance costs Curtin University].

Ilias, A., Suki, N. M., Yasoa', M. R., \& Abdul-Rahman, R. (2008). A study of taxpayers' intention in using efiling system: A case in Labuan F.Ts. Computer and Information Science, 1(2), 110 - 140. http://www.ccsenet.org/cis/CIS200802.pdf\#page=111

Inland Revenue Board of Malaysia. (2009). Annual report 2008.

Ismail, I. S., Shaharuddin, S. N. H., Shahroni, N. A. H., Ibrahim, N. M., \& Sani, U. R. M. (2021). The Effect of Trust and Ease of Use of E-filling on Tax Compliance in the Era of Big Data Analytics.

Kerlinger, F. N., Lee, H. B., \& Bhanthumnavin, D. (2000). Foundations of behavioural research: The most sustainable popular textbook by Kerlinger \& Lee (2000). In.

Krejcie, R. V., \& Morgan, D. W. (1970). Determining sample size for research activities. Educational and psychological measurement, 30(3), 607-610.

Lai, M. L., Obid, S. N. S., \& Meera, A.-K. (2004). Towards an electronic filing system: A Malaysian survey. eJournal of Tax Research, 2(1), 100-112. http://www.atax.unsw.edu.au/ejtr/content/previous_issues.htm

Lean, O. K., Zailani, S., Ramayah, T., \& Fernando, Y. (2009). Factors influencing intention to use egovernment services among citizens in Malaysia. International Journal of Information Management, 29(6), 458-475. $\quad$ http://www.sciencedirect.com/science/article/B6VB4-4XC97681/2/332db6cbda6090c560041bbe926756b5

Lee, J., Cerreto, F. A., \& Lee, J. (2010). Theory of planned behaviour and teachers' decisions regarding use of educational technology. Journal of Educational Technology \& Society, 13(1), 152-164.

Lu, C. T., Huang, S.-Y., \& Lo, P.-Y. (2010). An empirical study of on-line tax filing acceptance model: Integrating TAM and TPB. African journal of business management, 4(5), 800-810.

Lu, N. L. (2016). Online tax filing-e-government service adoption case of Vietnam. Modern Economy, 7(12), 1498.

Mamta, B. (2012). Tax Payers' Perception towards E-File Adoption: An Empirical Investigation. Journal of management and research, 5, 1-16.

Moore, G. C., \& Benbasat, I. (1991). Development of an Instrument to Measure the Perceptions of Adopting an Information Technology Innovation. Information Systems Research, 2(3), 192-222 https://doi.org/https://doi.org/10.1287/isre.2.3.192

Nik Muhammad, N. M., Jantan, M., \& Md Taib, F. (2010). Moderating effect of information processing capacity on investment decision making and environmental scanning. Business and Management Quarterly Review (BMQR), 1(1), 9-22.

Ojha, A., Sahu, G., \& Gupta, M. (2009). Antecedents of paperless income tax filing by young professionals in India: an exploratory study. Transforming Government: People, Process and Policy, 3(1), 65-90.

Ozgen, F. B., \& Turan, A. H. (2007, September 27-28). Usage and adoption of online tax filing and payment system in tax management: An empirical assessment with Technology Acceptance Model (TAM) in Turkey 9th International Scientific Conference, Management Horizons: Visions and Challenges, Vytautas Magnus University, Kaunas. http://papers.ssrn.com/sol3/papers.cfm?abstract_id=1012660

Rakhmawati, H., Sutrisno T, S., \& Khoiru R. M. (2020). Influence of TAM and UTAUTT models of the use of efiling on tax compliance. International Journal of Research in Business and Social Science, 9(9), 106111. https://doi.org/https://doi.org/10.20525/ijrbs.v9i1.576

Ramayah, T., Yusoff, Y. M., Jamaludin, N., \& Ibrahim, A. (2009). Applying the Theory of Planned Behavior (TPB) to predict internet tax filing intentions. International Journal of Management, 26(2), 272-284. http://search.ebscohost.com/login.aspx?direct=true\&db=bth\&AN=43465814\&site=ehost-live

Razak, F. Z. A., Bakar, A. A., \& Abdullah, W. S. W. (2020). E-filing users acceptance in Malaysia: Do government servant has enough technical proficiency? Journal of Physics: Conference Series,

Schaupp, L. C., \& Carter, L. (2009). Antecedents to e-file adoption: The U.S. citizen's perspective. eJournal of Tax Research, 7(2), 158-170.

Schaupp, L. C., Carter, L., \& McBride, M. E. (2010). E-file adoption: A study of U.S. taxpayers' intentions. Computers in Human Behavior, 26(4), 636-644. https://doi.org/10.1016/j.chb.2009.12.017

Sekaran, U., \& Bougie, R. (2016). Research methods for business: A skill-building approach. John Wiley \& Sons.

Sharma, D. R. S. K., Oman, S. O. F., \& Yadav, D. R. R. (2011). An empirical study on tax payer's attitudes towards e-return filing in India. International Journal of Research in Computer Application \& Management, 1(6), 20-24.

Suki, N. M., \& Ramayah, T. (2010). User acceptance of the e-government services in Malaysia: Structural equation modelling approach. Interdisciplinary Journal of Information, Knowledge, and Management, 5, 395-413. http://www.informingscience.us/icarus/journals/ijikm/publications 
Tahar, A., Riyadh, H. A., Sofyani, H., \& Purnomo, W. E. (2020). Perceived ease of use, perceived usefulness, perceived security and intention to use e-filing: The role of technology readiness. The Journal of Asian Finance, Economics, and Business, 7(9), 537-547.

Taylor, S., \& Todd, P. (1995). Understanding information technology usage: A test of competing models. Information Systems Research, 6(2), 144. http://sfx.lis.curtin.edu.au/sfx_local?sid=google\&auinit=S\&aulast=Taylor\&atitle=Understanding\%20infor mation\%20technology\%20usage $\% 3 \mathrm{~A} \% 20 \mathrm{~A} \% 20$ test $\% 20$ of\%20competing $\% 20$ models\&title=Information $\% 20$ Systems\%20Research\&volume $=6$ \&issue $=2 \&$ date $=1995 \&$ spage $=144 \&$ issn $=1047-7047$

Venkatesh, V., Morris, M. G., Gordon, B. D., \& Davis, F. D. (2003). User acceptance of information technology: Toward a unified view. MIS Quarterly, 27(3), 425-478. http://www.jstor.org/stable/30036540

Wang, Y. S. (2002). The adoption of electronic tax filing systems: an empirical study. Government Information Quarterly, 20(4), 333-352. http://www.sciencedirect.com/science/article/B6W4G-4B6SK9R2/2/04bdee026b95aab58c9d8a801138da4d

Wu, I. L., \& Chen, J. L. (2005). An extension of trust and TAM model with TPB in the initial adoption of online tax: An empirical study. International Journal of Human-Computer Studies, 62(6), 784-808. https://doi.org/10.1016/j.ijhcs.2005.03.003 